\title{
TAKEDOWN OF GLENN SHUNTS IN ADULTS WITH CONGENITAL HEART DISEASE WITH POLYTETRAFLUOROETHYLENE GRAFTS: TECHNIQUE AND LONG-TERM FOLLOW-UP
}

\author{
Elchanan Bruckheimer, MB, BS, ${ }^{a}$ Ziad R. Bulbul, MD, ${ }^{a}$ William E. Hellenbrand, MD, ${ }^{\text {a }}$ Charles S. Kleinman, MD, ${ }^{a}$ \\ and Gary S. Kopf, MD, ${ }^{b}$ New Haven, Conn.
}

The Glenn shunt, direct end-to-end anastomosis of the superior vena cava (SVC) to the right pulmonary artery (RPA), when first described in $1958,{ }^{1}$ provided a method of augmenting effective pulmonary blood flow in congenital heart disease. However, palliation by a Glenn shunt diminishes with time and often an additional shunt or definitive correction of the heart defect is required. ${ }^{2-5}$ Glenn shunt takedown during a corrective procedure has been reported rarely and mainly in children. ${ }^{3-5}$ We report herein successful takedown of a Glenn shunt in four adults, three during corrective procedures. In two patients reconstitution of pulmonary arterial continuity was done primarily for relief of severe unilateral left pulmonary hypertension.

Patients. Four patients who had undergone Glenn shunt takedown were identified in the database of patients who had undergone operation for congenital heart disease. The data and indications for Glenn shunt takedown are summarized in Table I. The Glenn shunt operation had been done for palliation of cyanosis at a mean age of 5 years. In patients 1 and 2 left pulmonary artery (LPA) hypertension developed as a result of a Blalock-Taussig shunt and a patent ductus arteriosus supplying the LPA, respectively. Glenn shunt takedown was done at a mean age of 29.5 years. All patients underwent cardiac catheterization before the operation.

Operative technique. Glenn shunt takedown and reestablishment of pulmonary artery continuity were performed via median sternotomy during cardiopulmonary bypass with venous cannulas placed in the inferior vena cava and innominate vein. Aortic crossclamping and cardioplegia were required in three patients for intracardiac repair or conduit replacement. Polytetrafluoroethylene (PTFE) grafts of 12 to $16 \mathrm{~mm}$ in diameter were used. The SVC was transected at the anastomosis to the RPA with particular care taken to identify and avoid injury to the right phrenic nerve. A ribbed PTFE graft was sewn to the main pulmonary artery or LPA, tunneled behind the ascending aorta, and the distal end sewn to the residual SVC stump on the RPA. In one instance, the

From the Sections of Pediatric Cardiology ${ }^{\mathrm{a}}$ and Pediatric Cardiothoracic Surgery, ${ }^{\mathrm{b}}$ Yale University School of Medicine and Children's Hospital at Yale-New Haven, New Haven, Conn.

Received for publication August 2, 1996; accepted for publication Sept. 17, 1996

Address for reprints: Elchanan Bruckheimer, MB, BS, Section of Pediatric Cardiology, Yale University School of Medicine, 333 Cedar St., New Haven, CT 06520.

J Thorac Cardiovasc Surg 1997;113:607-8

Copyright (C) 1997 by Mosby-Year Book, Inc.

$0022-5223 / 97 \$ 5.00+0 \quad \mathbf{1 2 / 5 4 / 7 8 0 3 6}$
SVC was transected at its junction with the innominate vein, because of difficulty in dissecting free the SVC-RPA junction, thereby incorporating a long segment of SVC in the pulmonary artery confluence. SVC-right atrial continuity was reestablished by a nonribbed PTFE graft from the distal segment of the transected SVC sutured directly to the anterolateral aspect of the right atrium. This was usually done during rewarming after intracardiac repair or conduit replacement. After operation the patients received warfarin therapy for at least 6 weeks.

Results and follow-up. All patients were alive at a mean follow-up of 7.7 years (range 3.7 to 16.3 years) and were free of cyanosis with a maintained or improved level of function. Two patients with LPA hypertension showed a marked decrease in pulmonary vascular resistance at follow-up cardiac catheterization from preoperative levels (Table II). The PTFE grafts were patent with no pressure gradients at the anastomoses. Patient 3 underwent cardiac catheterization 15 years after operation for assessment of subaortic obstruction with normal pulmonary hemodynamic findings and no pressure gradients at the anastomoses. Patient 4 had patent PTFE grafts on repeated color Doppler echocardiographic studies.

Discussion. We report the cases of four adults with long-standing Glenn shunt who underwent successful takedown and corrective operation with good results at longterm follow-up. Only nine similar cases have been reported, all but one in children, ${ }^{3,4}$ with the indications for the operation being increasing cyanosis and exercise intolerance. One series of five patients reported two deaths within 6 months of the operation with three patients having a good result at 2.5 years of follow-up. ${ }^{3}$ Another series of four children reported a good result in all patients at short-term follow-up. ${ }^{4}$ In one case report, pulmonary arterial continuity was restored primarily to relieve LPA hypertension into the previously "protected" low-pressure RPA and thereby improve the prognosis of corrective operation. ${ }^{5} \mathrm{We}$ adopted a similar approach in two adults with LPA hypertension complicating the results of previous aortopulmonary shunts with satisfying outcome (Table II).

Cardiopulmonary bypass was effective with venous cannulation of the inferior vena cava and innominate vein and allowed unobstructed access to the right atrium. Because of extensive scarring, operation involved prolonged and difficult dissection, particularly of the SVCRPA anastomosis, which led to inclusion of the SVC in the pulmonary arterial confluence in one case. In previous reports, restoration of pulmonary arterial and caval-atrial continuity was achieved with Dacron grafts or direct anastomoses. $^{3-5}$ Synthetic grafts were required in our adult patients to bridge the large distances caused by significant growth since the creation of the Glenn shunt. Prosthetic material in the venous system can predispose to 
Table I. Patient data

\begin{tabular}{|c|c|c|c|c|c|}
\hline Patient & Age (yr) & Diagnosis & Previous intervention & Indications & Operation \\
\hline 1 & 31 & TOF & $\begin{array}{l}\text { GS at } 4 \mathrm{yr} \text {, left BT shunt } \\
\text { at } 12 \mathrm{yr}\end{array}$ & $\begin{array}{l}\text { Suprasystemic RVP, LPA } \\
\text { hypertension }\end{array}$ & $\begin{array}{l}\text { GS takedown, PA reconstitution, } \\
\text { VSD patch, PV replacement }\end{array}$ \\
\hline 2 & 29 & PA-VSD & $\begin{array}{l}\text { GS at } 3 \mathrm{yr}, \mathrm{RV}-\mathrm{LPA} \\
\text { conduit at } 12 \mathrm{yr}, \mathrm{AV} \\
\text { fistulae embolization }\end{array}$ & $\begin{array}{l}\text { Suprasystemic RVP, LPA } \\
\text { hypertension, AV fistu- } \\
\text { las in RLL }\end{array}$ & $\begin{array}{l}\text { GS takedown, PA reconstitution, } \\
\text { conduit replacement }\end{array}$ \\
\hline 3 & 20 & $\begin{array}{l}\text { DORV, PS, } \\
\text { RPA stenosis }\end{array}$ & $\begin{array}{l}\text { GS at } 5 \mathrm{yr} \text {, atrial septec- } \\
\text { tomy }\end{array}$ & $\begin{array}{l}\text { Increasing cyanosis, exer- } \\
\text { cise intolerance }\end{array}$ & $\begin{array}{l}\text { GS takedown, PA reconstitution, } \\
\text { Rastelli procedure, ASD re- } \\
\text { pair }\end{array}$ \\
\hline 4 & 37 & TOF & $\begin{array}{l}\text { GS at } 10 \mathrm{yr} \text {, left } \mathrm{BT} \\
\text { shunt at } 18 \mathrm{yr}\end{array}$ & $\begin{array}{l}\text { Increasing cyanosis, exer- } \\
\text { cise intolerance, TIAs }\end{array}$ & $\begin{array}{l}\text { GS takedown, PA reconstitution, } \\
\text { TOF repair }\end{array}$ \\
\hline
\end{tabular}

$A S D$, Atrial septal defect; $A V$, arteriovenous; $B T$, Blalock-Taussig; $D O R V$, double-outlet right ventricle; $G S$, Glenn shunt; $L P A$, left pulmonary artery; $P A$, pulmonary artery; $P A-V S D$, pulmonary atresia-ventricular septal defect; $P S$, pulmonic stenosis, $P V$, pulmonary valve; $R L L$, right lower lobe; $R P A$, right pulmonary artery, $R V$, right ventricle; $R V P$, right ventricular pressure; $T I A$, transient ischemic attacks; $T O F$, tetralogy of Fallot, $V S D$, ventricular septal defect.

Table II. Pulmonary hemodynamics before and after Glenn shunt takedown

\begin{tabular}{|c|c|c|c|c|c|}
\hline \multirow[b]{2}{*}{ Patient } & \multirow{2}{*}{$\begin{array}{l}\text { Mean Glenn shunt } \\
\text { pressure }(\mathrm{mm} \mathrm{Hg})\end{array}$} & \multicolumn{2}{|c|}{$L P A$ pressure $(m m H g)$} & \multirow{2}{*}{$\begin{array}{l}\text { Left PVR (before) } \\
\text { (Wood units) }\end{array}$} & \multirow{2}{*}{$\begin{array}{c}\text { Total PVR (after) } \\
\text { (Wood units) }\end{array}$} \\
\hline & & Before & After & & \\
\hline 1 & 12 & $80 / 20(\mathrm{~m}=40)$ & $55 / 15(\mathrm{~m}=25)$ & $>20$ & 5 \\
\hline 2 & 20 & $120 / 40(\mathrm{~m}=65)$ & $50 / 20(\mathrm{~m}=30)$ & $>20$ & 7.4 \\
\hline
\end{tabular}

PVR, Pulmonary vascular resistance.

thrombosis; however, this was not observed. All patients received anticoagulation therapy after operation.

Glenn shunt takedown has not been recommended during a corrective procedure, because it may add risk and complexity. ${ }^{2}$ This has been our practice with uncomplicated Glenn shunt when the anteroposterior displacement of the pulmonary arteries was considerable or the right ventricle was of inadequate size. In selected adult patients, however, Glenn shunt takedown is feasible and obviates the long-term complications of the shunt, and the restoration of pulmonary arterial continuity can provide relief of unilateral LPA hypertension.

\section{REFERENCES}

1. Glenn WWL. Circulatory bypass of the right side of the heart: shunt between superior vena cava and distal right pulmonary artery-report of clinical application. N Engl J Med 1958;259: 117-20.

2. Kopf GS, Laks H, Stansel HC, Hellenbrand WE, Kleinman CS, Talner NS. Thirty-year follow-up of superior vena cavapulmonary artery (Glenn) shunts. J Thorac Cardiovasc Surg 1990;100:662-71.

3. Pacifico AD, Kirklin JW. Take-down of cava-pulmonary artery anastomosis (Glenn) during repair of congenital cardiac malformations. J Thorac Cardiovasc Surg 1975;70:272-7.

4. Rohmer J, Quaegebeur JM, Brom GA. Takedown and reconstruction of cavopulmonary anastomosis. Ann Thorac Surg 1977;23:129-34.

5. Marceletti C, Wallace RB, Ritter DG. Reconstruction of superior vena cava-right atrial continuity and "anatomic" repair of transposition of great arteries with ventricular septal defect. Mayo Clin Proc 1976;51:163-6. 